\title{
APLIKASI HEALTH BELIEF MODEL PADA PERILAKU MAHASISWI KESEHATAN MASYARAKAT DALAM PEMERIKSAAN PAYUDARA SENDIRI (SADARI)
}

\author{
Tanjung Anitasari Indah Kusumaningrum ${ }^{1 *}$, Nurlainiyah Kartika Sari ${ }^{2}$ \\ ${ }^{1,2}$ Program Studi Kesehatan Masyarakat Fakultas Ilmu Kesehatan Universitas \\ Muhammadiyah Surakarta. Jl. A. Yani, Pabelan, Kartasura, Surakarta. \\ Email: ${ }^{1}$ tanjung.anitasari@ums.ac.id, ${ }^{2}$ itskartikasa@gmail.com
}

\begin{abstract}
Abstrak
Jumlah kasus kanker payudara di Surakarta masih menjadi perhatian. SADARI perlu dilakukan pada wanita usia 20 tahun atau lebih (termasuk mahasiswi) untuk mendeteksi kanker payudara secara dini. Tujuan penelitian ini adalah menganalisis hubungan persepsi keseriusan, kerentanan, manfaat, hambatan, self efficacy, dan isyarat bertindak dengan perilaku SADARI pada mahasiswi kesehatan masyarakat di Universitas Muhammadiyah Surakarta. Jenis penelitian adalah observasional dengan rancangan cross sectional. Sampel penelitian adalah 106 mahasiswi kesehatan masyarakat yang diambil dengan proportional random sampling. Hasil penelitian ini didapat bahwa ada hubungan antara persepsi manfaat $(p$ value $=0,002)$, persepsi hambatan $(p$ value $=0,003)$, dan self efficacy $(p$ value $=$ $0,000)$ dengan perilaku SADARI namun tidak ada hubungan persepsi keseriusan $(p$ value $=0,565)$, persepsi kerentanan $(p$ value $=0,148)$, dan isyarat bertindak ( $p$ value $=0,108)$ dengan perilaku SADARI. Mahasiswi kesehatan masyarakat akan melakukan SADARI jika merasa bahwa SADARI memiliki manfaat yang lebih dari hambatan serta memiliki rasa mampu untuk melakukan SADARI.
\end{abstract}

Kata kunci : Health belief model, isyarat bertindak, perilaku SADARI, persepsi, self efficacy.

\begin{abstract}
The number of cases of breast cancer in Surakarta is still a concern. Breast Self Exam (BSE) needs to be done in women aged 20 years or older (including co-ed) to detect breast cancer early. The purpose of this research was to analyze the relationship of perception of the seriousness, the vulnerability, the benefits, barriers, self efficacy, and cues act with BSE on public health student at Muhammadiyah University of Surakarta. This type of research was observational cross sectional design. The research sample were 106 student public health were taken with proportional random sampling. The results of this research were obtained that there were relationship between the perception of benefits $(p$ value $=0.002)$, barriers $(p$ value $=0.003)$, and self efficacy ( $\mathrm{p}$ value $=0.000$ ) and BSE but no relationship perceptions of seriousness $(\mathrm{p}$ value $=0.565)$, vulnerability $(\mathrm{p}$ value $=$ 0.148 ), and cues Act ( $\mathrm{p}$ value $=0.108$ ) with BSE.Student public health
\end{abstract}


will do BSE if it feels that it is aware of the benefits of having more than the barriers and have a sense of being able to do BSE.

Keywords: Health belief model, cues to act, breast self exam, perception, self efficacy.

\section{PENDAHULUAN}

Salah satu jenis penyakit tidak menular yang menjadi perhatian adalah kanker payudara dengan persentase kasus baru $(43,3 \%)$ dan kematian akibat kanker payudara $(12,9 \%)$ (Pusdatin Kemenkes RI, 2015). Jumlah penderita kanker payudara di Indonesia sebesar 61.682 orang, dan pada tahun 2013 kanker payudara terbanyak terdapat di Jawa Tengah yaitu sebanyak 11.511 kasus (Pusdatin Kemenkes RI, 2015). Surakarta termasuk salah satu kota di Provinsi Jawa Tengah dengan jumlah kasus kanker payudara di Kota Surakarta pada tahun 2014 sebesar 4.943 kasus dan pada tahun 2015 kasus kanker payudara meningkat menjadi 9.320 kasus (Dinkes Surakarta, 2016).

Kasus kanker payudara dapat dicegah dengan pemeriksaan payudara sendiri (SADARI). SADARI merupakan upaya deteksi dini kanker payudara sehinggaberguna untuk menemukan gejala kanker payudara pada stadium awal dan pengobatan pun dapat lebih dini dilakukan (Savitri dkk., 2015). Jika deteksi dini dilakukan maka kanker payudara dapat terdeteksi lebih dini sehingga tingkat kesembuhan kanker payudara juga cukup tinggi yaitu 80\%-90\% (Rasjidi, 2009).

Wanita usia 20 tahun atau lebih merupakan usia yang tepat untuk melakukan SADARI secara rutin setiap bulan sehingga kelainan pada payudara dapat diketahui lebih dini dan dapat dilakukan penanganan secara tepat (Savitri dkk., 2015). Berdasarkan kelompok umur yang lebih baik melakukan SADARI, mahasiswi merupakan remaja yang telah mencapai usia 20 tahun sehingga seharusnya telah rutin melakukan SADARI. Universitas Muhammadiyah Surakarta (UMS) termasuk salah satu perguruan tinggi dengan Program Studi Kesehatan Masyarakat. Mahasiswi yang menempuh pendidikan di Program Studi Kesehatan Masyarakat UMS notabene akan lebih memahami mengenai upaya pencegahan suatu penyakit.

Menurut teori Health Belief Model (HBM), perilaku pencarian pelayanan kesehatan dipengaruhi oleh persepsi seseorang terhadap penyakit atau kondisi yang akan dialami. Jika seseorang menganggap dirinya rentan terhadap kondisi tersebut, percaya bahwa kondisi tersebut akan memiliki dampak serius, percaya bahwa tindakan pencegahan akan bermanfaat untuk mengurangi kerentanan dan keparahan suatu kondisi, dan percaya manfaat yang diharapkan akan lebih besar dari pada hambatan suatu tindakan, maka mereka akan cenderung melakukan tindakan untuk mengurangi risiko suatu penyakit. (Glanz dan Viswanath, 2008). Berdasarkan Al Harbi dkk. (2017) dinyatakan bahwa diperlukannya upaya untuk meningkatkan persepsi remaja putri mengenai kanker payudara dan SADARI, dan penelitian ini juga mendorong lebih dilakukan penelitian untuk mengeksplor persepsi mengenai kanker payudara dan SADARI melalui penelitian kuantitatif.

Berdasarkan survey pendahuluan terhadap 10 mahasiswi kesehatan masyarakat UMS didapatkan hasil bahwa hanya 1 mahasiswi yang melakukan SADARI secara rutin tiap bulan. Pentingnya SADARI sebagai upaya deteksi dini kanker payudara sementara masih sedikitnya mahasiswi kesehatan 
masayarakat UMS yang melakukan SADARI maka peneliti tertarik untuk meneliti mengenai "Aplikasi Health Belief Model pada Perilaku Mahasiswi Kesehatan Masyarakat dalam Pemeriksaan Payudara Sendiri (SADARI) di Universitas Muhammadiyah Surakarta.

\section{METODE PENELITIAN}

Jenis penelitian ini adalah observasional dengan rancangan cross sectional yang dilakukan pada bulan Mei 2017 di Universitas Muhammadiyah Surakarta. Populasi penelitian ini adalah mahasiswi kesehatan masyarakat angkatan tahun 2013-2015 Universitas Muhammadiyah Surakarta yang berjumlah 254 orang. Sampel dalam penelitian ini sejumlah 106 mahasiswi angkatan tahun 2013-2015.Teknik pengambilan sampel menggunakan proportional random sampling. Analisis data dalam penelitian ini yaitu analisis univariat dan bivariate. Analisis bivariat dilakukan dengan menggunakan ChiSquare.

\section{HASIL DAN PEMBAHASAN}

\section{A. Karakteristik Responden}

Berdasarkan karakteristik usia, ratarata usia mahasiswi adalah $21,07 \pm 0,854$ tahun, sebagian besar berusia 21 tahun sebanyak 41 orang $(38,7 \%)$. Usia responden termuda yaitu 20 tahun dan tertua berusia 23 tahun. Berdasarkan karakteristik riwayat keluarga diketahui bahwa dari 106 mahasiswi terdapat 6 orang $(5,7 \%)$ memiliki riwayat keluarga yang menderita kanker payudara. Distribusi frekuensi karakteristik responden berdasarkan usia dapat dilihat pada Tabel 1.

Pada Tabel 2. menunjukkan bahwa mayoritas responden memiliki persepsi tentang kanker payudara yang serius yaitu 54 responden (51\%). Mayoritas responden juga memiliki persepsi bahwa dirinya kurang rentan terkena kanker payudara yaitu 62 responden (58\%). Mayoritas responden memiliki persepsi manfaat tentang SADARI yang tinggi yaitu 54 responden (51\%). Sebagian besar responden memiliki persepsi hambatan yang tinggi untuk melakukan SADARI yaitu 67 responden (63\%). Sebagian besar responden memiliki self efficacy yang rendah untuk melakukan SADARI yaitu 63 responden (59\%). Mayoritas responden memiliki isyarat bertindak yang rendah yaitu 59 responden (56\%). Sebagian besar responden melakukan SADARI yaitu 55 responden $(52 \%)$.

Tabel 1. Distribusi Frekuensi Karakteristik Responden Berdasarkan Usia

\begin{tabular}{ccccccc}
\hline $\begin{array}{c}\text { Karakteristik } \\
\text { Responden }\end{array}$ & n & \% & Mean & SD & Min & Max \\
\hline Usia & 31 & 29,2 & & & & \\
20 & 41 & 38,7 & & & & \\
21 & 30 & 28,3 & & & & \\
22 & 4 & 3,8 & 21,07 & 0,854 & 20 & 23 \\
23 & & & & & & \\
Riwayat Keluarga & & & & & \\
Tidak ada & 100 & 94,3 & & & \\
Ada & 6 & 5,7 & & & & \\
\hline Total & $\mathbf{1 0 6}$ & $\mathbf{1 0 0}$ & & &
\end{tabular}


Tabel 2. Distribusi Frekuensi Berdasarkan Persepsi Keseriusan, Kerentanan, Manfaat, Hambatan, Self Efficacy, Isyarat Bertindak, dan Perilaku SADARI

\begin{tabular}{lcc}
\hline \multirow{2}{*}{\multicolumn{1}{c}{ Variabel }} & \multicolumn{2}{c}{ Jumlah } \\
\cline { 2 - 3 } & F & (\%) \\
\hline Persepsi Keseriusan & 54 & 51 \\
Serius & 52 & 49 \\
Kurang Serius & & \\
Persepsi Kerentanan & 44 & 42 \\
Rentan & 62 & 58 \\
Kurang Rentan & & \\
Persepsi Manfaat & 54 & 51 \\
Tinggi & 52 & 49 \\
Rendah & & \\
Persepsi Hambatan & 39 & 37 \\
Rendah & 67 & 63 \\
Tinggi & & \\
Self Efficacy & 43 & 41 \\
Tinggi & 63 & 59 \\
Rendah & & \\
Isyarat Bertindak & 47 & 44 \\
Tinggi & 59 & 56 \\
Rendah & & \\
Perilaku SADARI & & 52 \\
Melakukan SADARI & 55 & 48 \\
Tidak Melakukan SADARI & 51 & 100 \\
\hline Jumlah & 106 & \\
\hline
\end{tabular}

Tabel 3. Distribusi Frekuensi Berdasarkan Persepsi Keseriusan, Kerentanan, Manfaat, Hambatan, Self Efficacy, Isyarat Bertindak, dan Perilaku SADARI

\begin{tabular}{|c|c|c|c|c|c|c|c|}
\hline \multirow{3}{*}{ Variabel } & \multicolumn{4}{|c|}{ Niat VCT } & \multirow{2}{*}{\multicolumn{2}{|c|}{ Total }} & \multirow{3}{*}{$P$ Value } \\
\hline & \multicolumn{2}{|c|}{ Sadari } & \multicolumn{2}{|c|}{ Tidak Sadari } & & & \\
\hline & (n) & $(\%)$ & (n) & $(\%)$ & (n) & $(\%)$ & \\
\hline \multicolumn{8}{|l|}{ Keseriusan } \\
\hline Serius & 30 & 56 & 24 & 44 & 54 & 100 & 0,565 \\
\hline Kurang serius & 25 & 48 & 27 & 52 & 52 & 100 & \\
\hline \multicolumn{8}{|l|}{ Kerentanan } \\
\hline Rentan & 27 & 61 & 17 & 39 & 44 & 100 & 0,148 \\
\hline Kurang rentan & 28 & 45 & 34 & 55 & 62 & 100 & \\
\hline \multicolumn{8}{|l|}{ Manfaat } \\
\hline Tinggi & 31 & 70 & 13 & 30 & 44 & 100 & 0,002 \\
\hline Rendah & 24 & 39 & 38 & 61 & 62 & 100 & \\
\hline \multicolumn{8}{|l|}{ Hambatan } \\
\hline Rendah & 28 & 72 & 11 & 28 & 39 & 100 & 0,003 \\
\hline Tinggi & 27 & 40 & 40 & 60 & 67 & 100 & \\
\hline \multicolumn{8}{|l|}{ Kemampuan } \\
\hline Tinggi & 33 & 77 & 10 & 23 & 43 & 100 & 0,000 \\
\hline Rendah & 22 & 35 & 41 & 65 & 63 & 100 & \\
\hline \multicolumn{8}{|l|}{ Isyarat } \\
\hline Tinggi & 29 & 62 & 18 & 38 & 47 & 100 & 0,108 \\
\hline Rendah & 26 & 44 & 33 & 56 & 59 & 100 & \\
\hline
\end{tabular}




\section{Hubungan \\ Keseriusan \\ Pemeriksaan \\ (SADARI) \\ Kesehatan \\ Universitas \\ Surakarta}

Berdasarkan hasil uji chi-square didapatkan nilai $p$-value $0,565>0,05$ sehingga dapat disimpulkan bahwa tidak ada hubungan antara persepsi keseriusan dengan Perilaku SADARI mahasiswi kesehatan masyarakat di Universitas Muhammadiyah Surakarta. Hasil penelitian ini tidak sejalan dengan penelitian Delviani dan Priscilla (2014) bahwa terdapat hubungan antara persepsi keparahan dengan perilaku SADARI di Fakultas Keperawatan Universitas Andalas. Hasil penelitian ini juga tidak sejalan dengan penelitian Oktaviana (2015) bahwa terdapat hubungan antara persepsi keseriusan penyakit dengan penggunaan skrining Inspeksi Visual Asam setat (IVA) pada Wanita Usia Subur.

Hasil penelitian ini menunjukkan bahwa responden yang melakukan SADARI cenderung memiliki persepsi yang serius terhadap kanker payudara yaitu sejumlah 30 responden $(56 \%)$ sedangkan responden yang tidak melakukan SADARI cenderung memiliki persepsi yang kurang serius terhadap kanker payudara yaitu sejumlah 27 responden $(52 \%)$. Penelitian ini sejalan dengan Becker (1974) dalam Fitriani (2011) yaitu perilaku seseorang ditentukan oleh anggapan seseorang apakah suatu masalah serius atau apakah kanker payudara serius. Jika seseorang berpikir tentang penyakit itu serius maka perilaku pencegahan juga akan meningkat yaitu jika seseorang berpikir kanker payudara itu serius maka perilaku SADARI juga akan dilakukan.

Berdasarkan hasil jawaban responden, responden memiliki persepsi keseriusan yang tinggi mengenai responden merasa takut jika berbicara tentang kanker payudara $(61,3 \%)$. Responden juga memiliki pandangan bahwa kanker payudara adalah penyakit yang berbahaya $(64,1 \%)$. Selain itu responden merasa bahwa kanker payudara dapat merubah bentuk payudara $(95,2 \%)$. Hal ini sesuai dengan Savitri dkk. (2015) yang menyatakan bahwa gejala kanker payudara salah satunya adalah perubahan bentuk dan ukuran payudara.

Responden juga beranggapan bahwa SADARI dapat mengecilkan peluang terkena kanker payudara (91,9\%), dan SADARI dapat mencegah kanker payudara $(88,7 \%)$. Hal ini sesuai dengan Kemenkes RI (2016) yang menyatakan bahwa SADARI adalah deteksi dini untuk mencegah kanker payudara. Apabila melakukan SADARI maka masyarakat dapat mendeteksi secara awal penyakit kanker payudara serta dapat mengetahui perubahan-perubahan yang terjadi pada payudaraa seperti bentuk dan ukuran payudara, benjolan pada payudara.

\section{Hubungan antara Persepsi Kerentanan dengan Perilaku Pemeriksaan Payudara Sendiri (SADARI) pada Mahasiswi Kesehatan Masyarakat di Universitas Muhammadiyah Surakarta}

Berdasarkan hasil uji chi-square didapatkan nilai $p$-value $0,148>0,05$ sehingga dapat disimpulkan bahwa tidak ada hubungan antara persepsi kerentanan dengan Perilaku SADARI mahasiswi kesehatan masyarakat di Universitas Muhammadiyah Surakarta. Hasil penelitian ini tidak sejalan dengan penelitian Delviani dan Priscilla (2014) bahwa terdapat hubungan antara persepsi kerentanan dengan perilaku SADARI di Fakultas Keperawatan Universitas Andalas. Hasil penelitian ini juga tidak sejalan dengan penelitian Oktaviana 
(2015) bahwa terdapat hubungan antara persepsi kerentanan individu dengan penggunaan skrining Inspeksi Visual Asam setat (IVA) pada Wanita Usia Subur.

Hasil penelitian ini menunjukkan bahwa responden yang melakukan SADARI cenderung memiliki persepsi bahwa mereka rentan terhadap kanker payudara yaitu sejumlah 27 responden (61\%) sedangkan responden yang tidak melakukan SADARI cenderung memiliki persepsi yang kurang rentan terhadap kanker payudara yaitu sejumlah 34 responden (55\%). Hal ini sesuai dengan Kholid (2014) yang menyatakan bahwa seseorang akan melakukan perilaku mencari tes penyaringan atau pemeriksaan untuk penyakit jika orang tersebut percaya bahwa ia dapat memiliki penyakit tersebut atau ia rentan terkena penyakit tersebut. Begitu halnya dengan perilaku SADARI pada mahasiswi kesehatan masyarakat UMS, mahasiswi tidak akan melakukan SADARI jika tidak merasa rentan terkena kanker payudara. Penelitian ini juga sejalan dengan Guilford (2011) yang menyatakan bahwa persepsi kerentanan pada mahasiswi berada pada level yang rendah sehingga diperlukan program pendidikan mengenai SADARI yang sesuai dengan kebutuhan mahasiswi.

Penelitian ini juga sesuai dengan Chong dkk. (2014) yang menyatakan bahwa pengetahuan tentang SADARI dan faktor risiko kanker payudara berhubungan dengan praktek SADARI. Pengetahuan tentang faktor risiko kanker payudara akan berkaitan dengan persepsi kerentanan. Jika pengetahuan baik tentang faktor risiko kanker payudara maka seseorang akan merasa rentan terkena kanker payudara sehingga Ia akan melakukan SADARI.

Berdasarkan hasil jawaban responden, responden merasa bahwa mereka memiliki peluang untuk terkena kanker payudara $(61,3 \%)$. Hal ini sesuai dengan Kemenkes RI (2016) yang menyatakan bahwa kanker payudara merupakan penyakit dengan prevalensi tertinggi di Indonesia pada tahun 2013 $\left(0,5 \%_{0}\right)$. Namun ada pula responden yang tidak merasa rentan terhadap kanker payudara karena rajin aktivitas fisik (61,3\%). Anggapan responden tersebut sesuai dengan pesan CERDIK dalam Kemenkes RI (2016) yaitu upaya pencegahan kanker payudara dapat dilakukan dengan rajin aktifitas fisik. Aktifitas fisik dapat menurunkan risiko kanker payudara, seperti halnya hasil penelitian Karima dan Wahyono (2013) yang menyatakan bahwa semakin lama aktivitas fisik berat dilakukan maka semakin menurunkan risiko kanker payudara. Namun terdapat banyak faktor lain yang berhubungan dengan kanker payudara yaitu obesitas, usia melahirkan anak pertama, riwayat pemberian ASI, dan usia menarche (Anggorowati, 2013).

\section{Hubungan antara Persepsi Manfaat dengan Perilaku Pemeriksaan Payudara Sendiri (SADARI) pada Mahasiswi Kesehatan Masyarakat di Universitas Muhammadiyah Surakarta}

Berdasarkan hasil uji chi-square didapatkan nilai $p$-value $0,002<0,05$ sehingga dapat disimpulkan bahwa ada hubungan antara persepsi manfaat dengan Perilaku SADARI mahasiswi kesehatan masyarakat di Universitas Muhammadiyah Surakarta. Hasil penelitian ini sejalan dengan penelitian Delviani dan Priscilla (2014) bahwa terdapat hubungan antara persepsi manfaat dengan perilaku SADARI di Fakultas Keperawatan Universitas Andalas. Hasil penelitian ini juga sejalan dengan penelitian Oktaviana (2015) bahwa terdapat hubungan antara persepsi manfaat dengan penggunaan skrining Inspeksi Visual Asam setat (IVA) pada Wanita Usia Subur. 
Hasil penelitian ini menunjukkan bahwa responden yang melakukan SADARI cenderung memiliki persepsi manfaat yang tinggi terhadap SADARI yaitu sejumlah 31 responden $(70 \%)$ sedangkan responden yang tidak melakukan SADARI cenderung memiliki persepsi manfaat yang rendah terhadap SADARI yaitu sejumlah 38 responden $(61 \%)$. Hal ini sesuai dengan Fitriani (2011) yang menyatakan bahwa dalam melakukan tindakan pencegahan tergantung pada pertimbangan untung rugi. Jika seseorang berkeyakinan bahwa manfaat yang berasal dari perilaku yang direkomendasikan lebih besar dari biaya dan ketidaknyamanan maka seseorang akan melakukan perilaku kesehatan (Kholid, 2012).

Berdasarkan hasil jawaban responden, responden memiliki persepsi manfaat yang tinggi mengenai manfaat SADARI yaitu SADARI dapat membantu menemukan benjolan di payudara (98,2\%). Responden juga memiliki persepsi manfaat akan SADARI yang tinggi yaitu (96,2\%). Hal ini sesuai dengan Hal ini sesuai dengan Kemenkes RI (2016) yang menyatakan bahwa SADARI dapat mengetahui benjolan pada payudara. Namun responden juga ada yang memiliki persepsi bahwa SADARI dapat menghabiskan banyak waktu (97,2\%). Persepsi responden tersebut timbul karena masih adanya responden yang tidak melakukan SADARI (48\%) sehingga responden tidak mengetahui lama waktu dalam melakukan SADARI. Sehingga perlu diberikan pemahaman kepada mahasiswa di dalam mata kuliah kesehatan reproduksi mengenai langkahlangkah SADARI dan durasi waktu SADARI. Mahasiswa juga diharapkan lebih aktif dalam mencari informasi mengenai kesehatan reproduksi khususnya SADARI dari berbagai sumber informasi di luar perkuliahan seperti buku maupun iklan layanan masyarakat.

\section{Hubungan antara Persepsi Hambatan dengan Perilaku Pemeriksaan Payudara Sendiri (SADARI) pada Mahasiswi Kesehatan Masyarakat di Universitas Muhammadiyah Surakarta}

Berdasarkan hasil uji chi-square didapatkan nilai $p$-value $0,003<0,05$ sehingga dapat disimpulkan bahwa ada hubungan antara persepsi hambatan dengan Perilaku SADARI mahasiswi kesehatan masyarakat di Universitas Muhammadiyah Surakarta. Hasil penelitian ini sejalan dengan penelitian Delviani dan Priscilla (2014) bahwa terdapat hubungan antara persepsi hambatan dengan perilaku SADARI di Fakultas Keperawatan Universitas Andalas. Hasil penelitian ini juga sejalan dengan penelitian Oktaviana (2015) bahwa terdapat hubungan antara persepsi hambatan dengan penggunaan skrining Inspeksi Visual Asam setat (IVA) pada Wanita Usia Subur. Umeh dan Gibson (2010) juga menjelaskan bahwa tingkat keparahan dan hambatan merupakan prediktor penting untuk perilaku SADARI.

Faktor hambatan responden yang melakukan SADARI cenderung memiliki persepsi hambatan yang rendah terhadap SADARI yaitu sejumlah 28 responden $(72 \%)$ sedangkan responden yang tidak melakukan SADARI cenderung memiliki persepsi hambatan yang tinggi terhadap SADARI yaitu sejumlah 40 responden (60\%). Hal ini sesuai dengan Glanz dkk. (2008) yang menyatakan bahwa perilaku dipengaruhi oleh persepsi terkait aspekaspek negatif dari tindakan yang dirasakan oleh seseorang.

Berdasarkan hasil jawaban responden, responden merasa hambatan dalam melakukan SADARI adalah malu $(94,3 \%)$, dapat menyakiti tubuh $(97,2 \%)$, waktu yang lama $(92,5 \%)$, mengganggu aktivitas $(97,2 \%)$, serta tidak mampu 
melakukan sadari $(94,4 \%)$. Berbagai anggapan tersebut dapat terjadi mengingat masih ada responden yang belum mengetahui langkah-langkah SADARI yaitu ditunjukkan dengan masih terdapat mahasiswa yang tidak melakukan SADARI hingga daerah ketiak $(53,8 \%)$, SADARI melingkar puting $(53,7 \%)$. Hal ini sesuai dengan Sari (2017) yang menyatakan bahwa sebanyak 47,2\% mahasiswi tidak mengetahui perkembangan kanker payudara serta mahasiswi juga tidak mengetahui jika SADARI dapat dilakukan dengan berbaring. Hambatan dalam melakukan SADARI yang lebih mengarah kepada kurangnya aspek pengetahuan mengenai cara melakukan SADARI sesuai dengan penelitian Karayurt dkk. (2008) yang menunjukkan bahwa alasan umum tidak dilakukannya SADARI adalah tidak diketahuinya bagaimana cara melakukan SADARI yang benar. Sehingga mahasiswa perlu mencari sumber informasi di luar perkuliahan mengenai langkah-langkah SADARI seperti melalui seminar kesehatan sehingga mahasiswi dapat merasa mampu untuk melakukan SADARI.

\section{Hubungan antara Self Efficacy dengan Perilaku Pemeriksaan Payudara Sendiri (SADARI) pada Mahasiswi Kesehatan Masyarakat di Universitas Muhammadiyah Surakarta}

Berdasarkan hasil uji chi-square didapatkan nilai $p$-value $0,000<0,05$ sehingga dapat disimpulkan bahwa ada hubungan antara self efficacy dengan Perilaku SADARI mahasiswi kesehatan masyarakat di Universitas Muhammadiyah Surakarta. Hasil penelitian ini sesuai dengan Yuniar (2018) yang menyatakan bahwa self efficacy berhubungan dengan perilaku SADARI. Penelitian lain yang juga sejalan adalah Putri (2017) yang menyatakan bahwa self efficacy berhubungan signifikan dengan perilaku periksa payudara sendiri (SADARI) pada wanita di Kecamatan Tegalrejo Kota Yogyakarta.

Responden yang melakukan SADARI cenderung memiliki self efficacy yang tinggi terhadap SADARI yaitu sejumlah 33 responden (77\%) sedangkan responden yang tidak melakukan SADARI cenderung memiliki self efficacy yang rendah terhadap SADARI yaitu sejumlah 41 responden $(65 \%)$. Hal ini sesuai dengan Glanz dkk. (2008) yang menyatakan bahwa konsep isyarat dapat memicu seseorang untuk bertindak.

Berdasarkan hasil jawaban responden, responden akan tetap melakukan SADARI walaupun tidak ada dukungan teman untuk SADARI $(95,3 \%)$, tidak ada dukungan orang tua $(94,3 \%)$. Responden juga akan melakukan SADARI jika ada petunjuk melakukan SADARI (99\%). Sehingga dapat disimpulkan petunjuk atau langkahlangkah SADARI sangat dibutuhkan oleh mahasiswi atau responden untuk melakukan SADARI karena walaupun pihak luar tidak mendukung SADARI asalkan ada petunjuknya tentang SADARI maka mahasiswi akan melakukan SADARI. Petunjuk pelaksanaan SADARI akan dapat memperluas pengetahuan seseorang untuk melakukan SADARI. Jika pengetahuan seseorang kurang tentang SADARI maka akan berhubungan dengan rendahnya praktek SADARI pada pelajar (Isara dan Ojedokun, 2011). Sehingga petunjuk mengenai SADARI dapat dilakukan melalui pendidikan kesehatan kepada mahasiswi baik melalui mata kuliah maupun media cetak dan elektronik seperti halnya hasil penelitian Doshi dkk. (2012) yang menyatakan bahwa perlunya program pendidikan untuk meningkatkan kesadaran akan perlunya melakukan pemeriksaan payudara sendiri. 


\section{Hubungan antara Isyarat Bertindakdengan Perilaku Pemeriksaan Payudara Sendiri (SADARI) pada Mahasiswi Kesehatan Universitas Surakarta}

Berdasarkan hasil uji chi-square didapatkan nilai $p$-value $0,108>0,05$ sehingga dapat disimpulkan bahwa tidak ada hubungan antara isyarat bertindak dengan Perilaku SADARI mahasiswi kesehatan masyarakat di Universitas Muhammadiyah Surakarta. Hasil penelitian ini menunjukkan bahwa responden yang melakukan SADARI cenderung memiliki isyarat bertindak yang tinggi terhadap SADARI yaitu sejumlah 29 responden (62\%) sedangkan responden yang tidak melakukan SADARI cenderung memiliki isyarat bertindak yang rendah terhadap SADARI yaitu sejumlah 33 responden (56\%).

Isyarat bertindak yang mendapatkan skor jawaban tertinggi adalah responden akan melakukan SADARI jika terdapat anjuran kesehatan $(89,6 \%)$. Hal ini sesuai dengan teori S-O-R yang menyatakan bahwa seserang akan melakukan tindakan sebagai respons terhadap stimulus seperti halnya seseorang akan melakukan SADARI jika terdapat anjuran kesehatan (Kholid, 2012). Anjuran kesehatan dapat dilakukan melalui program pendidikan dan pelatihan kesehatan. Hal ini sesuai dengan hasil penelitian Ahmed dkk. (2017) yang menyatakan bahwa pengetahuan dan praktik remaja akan SADARI akan meningkat setelah menerima program pelatihan SADARI yaitu $68,9 \%$ remaja melakukan SADARI dan $31,2 \%$ remaja melakukan SADARI secara rutin setelah pelatihan.

\section{KESIMPULAN}

Mayoritas responden memiliki persepsi tentang kanker payudara yang serius yaitu 54 responden (51\%). Mayoritas responden juga memiliki persepsi bahwa dirinya kurang rentan terkena kanker payudara yaitu 62 responden $(58 \%)$. Sementara pada aspek persepsi manfaat, mayoritas responden memiliki persepsi manfaat tentang SADARI yang tinggi yaitu 54 responden $(51 \%)$. Sebagian besar responden memiliki persepsi hambatan yang tinggi untuk melakukan SADARI yaitu 67 responden (63\%). Sebagian besar responden memiliki self efficacy yang rendah untuk melakukan SADARI yaitu 63 responden (59\%). Mayoritas responden memiliki isyarat bertindak yang rendah yaitu 59 responden (56\%). Sebagian besar responden melakukan SADARI yaitu 55 responden $(52 \%)$.

Variabel yang berhubungan dengan perilaku SADARI adalah persepsi manfaat $(p$ value $=0,002)$, hambatan $(p$ value $=$ $0,003)$, dan self efficacy ( $p$ value $=0,000)$. Sementara persepsi keseriusan $(p$ value $=$ $0,565)$, kerentanan ( $p$ value $=0,148)$, dan isyarat bertindak ( $p$ value $=0,108)$ tidak berhubungan dengan perilaku SADARI pada mahasiswi kesehatan masyarakat.

Diperlukan upaya untuk mengurangi hambatan untuk melakukan SADARI seperti halnya dengan pemberian pendidikan atau edukasi mengenai langkah-langkah melakukan SADARI serta lama waktu melakukan SADARI. Upaya ini dapat dilakukan oleh institusi pendidikan maupun DKK Surakarta. 
Rekomendasi penelitian lebih lanjut adalah penelitian dengan rancangan quasi eksperimental yaitu dengan memberikan perlakuan berupa pemberian Komunikasi Informasi dan Edukasi mengenai SADARI yang mana media pendidikannya disesuaikan dengan kebutuhan mahasiswi (seperti halnya penggunaan media sosial dan kampanye).
Diperlukan juga penelitian lebih lanjut kepada mahasiswi non kesehatan serta wanita usia produktif.

\section{UCAPAN TERIMA KASIH}

Ucapan terimakasih diberikan pada Universitas Muhammadiyah Surakarta yang telah mendukung penelitian ini.

\section{DAFTAR PUSTAKA}

Ahmed, A.M., Hamed, A.A.A.E., Azzam, H.F., \& Elaziz, M.A. (2017). Effect of Breast Self Examination Training Program on Knowledge and Practice of Adolescent Girls. International Journal of Research in Applied, Natural and Social Sciences, 5(2): 35-48.

Al Harbi, M.F., Al Haji, K., Moawed, S.A.E.A., \& Hawsawi, A. (2017). Using Health Belief Model to Probe Female Adolescent Perception About Breast Cancer in Riyadh City. American Journal of Nursing Science, 6(4): 358-365.

Anggorowati, L. (2013). Faktor Risiko Kanker Payudara Wanita. Jurnal Kesehatan Masyarakat, 8 (2): 121-126.

A.R. Isara \& Ojedokun. (2011). Knowledge of Breast Cancer and Practice of Breast Self Examination Among Female Senior Secondary School Students in Abuja, Nigeria. J Prev Med Hyg, 52; 186-190.

Bustan, M.N. (2015). Manajemen Pengendalian Penyakit Tidak Menular. Rineka Cipta, Jakarta.

Chong, C.C., Coomarasamy, J.D, \& Suppayah B. (2014). Perception of Breast Health amongst Malaysian Female Adolescents. Asian Pacific Journal of Cancer Prevention, 15(17): 7175-7180.

Delviani, R \& Priscilla, V. (2015). Persepsi Mahasiswi tentang Kanker Payudara dan Perilakunya terhadap Pencegahan Kanker Payudara di Fakultas Keperawatan Universitas Andalas. Ners Jurnal Keperawatan, 10 (1).

Dinas Kesehatan Kota Surakarta. (2016). Profil Kesehatan Kota Surakarta Tahun 2015. Surakarta: Dinas Kesehatan Kota Surakarta.

Doshi, D., Reddy, B.S., Kulkarni, S., \& Karunakar, P. (2012). Breast Self-Examination: Knowledge, Attitude, and Practice among Female Dental Students in Hyderabad City. Indian Journal of Palliative Care. 18 (1):68-73.

Fitriani, S. (2011). Promosi Kesehatan. Graha Ilmu, Yogyakarta.

Glanz, K. Barbara, K. \& Viswanath. (2008). Health Behavior And Health Education Theory, Research, and Practice. Jossey-Bass, US.

Guilford, K. (2011). Breast Cancer Knowledge, Beliefs, and Screening Behaviors of College Women: Utilization of The Health Belief Model. (Disertasi). Department of Health Science in The Graduate School of The University of Alabama.

Karayurt, Ö; Özmen, d \& ÇetinkayaA, Ç. (2008). Awereness of Breast Cancer Risk Factors and Practice of Breast Self Examination among High School Students in Turkey. BMC Public Health. 8: 359. 
Kementerian Kesehatan Republik Indonesia. (2015). Pusat Data dan Informasi Kementerian Kesehatan RI Situasi Penyakit Kanker. Kementerian Kesehatan Republik Indonesia, Jakarta.

Kementerian Kesehatan Republik Indonesia. (2016). Pusat Data dan Informasi Kementerian Kesehatan RI Bulan Peduli Kanker Payudara. Kementerian Kesehatan Republik Indonesia, Jakarta.

Kholid, A. (2014). Promosi Kesehatan dengan Pendekatan Teori Perilaku, Media, dan Aplikasinya. PT Raja Grafindo Persada, Jakarta.

Notoatmodjo, S. (2007). Promosi Kesehatan dan Ilmu Perilaku. PT. Rineka Cipta, Jakarta.

Oktaviana, M.N. (2015). Hubungan Persepsi Kerentanan Individu, Keseriusan Penyakit, Manfaat, dan Hambatan dengan Penggunaan Skrining Inspeksi Visual Asam Asetat (IVA) pada Wanita Usia Subur. (Tesis). Magister Ilmu Kesehatan Masyarakat Universitas Sebelas Maret, Surakarta.

Olfah, Y., Mendri, N. K., \& Badi'ah, A. (2013). Kanker Payudara \& SADARI. Nuha Medika, Yogyakarta.

Putri, I.M. (2017). Hubungan Self Efficacy dengan Perilaku Periksa Payudara Sendiri (SADARI) pada Wanita di Kecamatan Tegalrejo Kota Yogyakarta. (Tesis). Fakultas Ilmu Kesehatan Universitas 'Aisyiyah Yogyakarta.

Rasjidi, I. (2009). Deteksi Dini \& Pencegahan Kanker pada Wanita. Sagung Seto, Jakarta.

Sari, N.K. (2017). Faktor-Faktor yang Berhubungan dengan Perilaku Pemeriksaan Payudara Sendiri (SADARI) Pada Mahasiswi Kesehatan Masyarakat di Universitas Muhammadiyah Surakarta. (Skripsi). Kesehatan Masyarakat Universitas Muhammadiyah Surakarta, Surakarta.

Savitri, A., Alina L., \& Utami, E.D.R. (2015). Kupas Tuntas Kanker Payudara, Leher Rahim dan Rahim. Pustaka Baru Press, Yogyakarta.

Soemitro, M.P. (2012). Blak-blakan Kanker Payudara: Temukan Sedini Mungkin. Qanita, Bandung.

Ulya Q, K., \& Wahyono, T.Y.M. (2013). Faktor-Faktor yang Berhubungan dengan Kejadian Kanker Payudara Wanita di Rumah Sakit Umum Pusat Nasional (RSUPN) dr. Cipto Mangunkusumo Jakarta Tahun 2013. Fakultas Kesehatan Masyarakat Universitas Indonesia.

Umeh, K. \& Gibson, J.R. (2001). Perceptions of Threat, Benefits, and Barriers in Breast Self Examination Amongst Young Asymptomatic Women. British Journal of Health Psychology. 2001 Nov;6(Part 4):361-372.

Yuniar, Z.F. (2018). Hubungan Antara Faktor Personal dan Self Efficacy dengan Perilaku Deteksi Dini Kanker Payudara pada Mahasiswi S1 Kesehatan Masyarakat Universitas Airlangga. (Skripsi). FKM Universitas Airlangga. 